\title{
IMPLEMENTASI NILAI-NILAI PANCASILA BAGI SISWA DI ERA GLOBALISASI
}

\author{
Ambiro Puji Asmaroini*
}

\begin{abstract}
Abstrak
alam rangka mengembangkan potensi peserta didik agar menjadi manusia yang beriman dan bertakwa kepada Tuhan Yang Maha Esa, berakhlak mulia, sehat, berilmu, cakap, kreatif, mandiri, dan menjadi warga negara yang demokratis serta bertanggung jawab, maka diperlukannya pendidikan yang tidak terlepas dari ajaran Pancasila sebagai dasar untuk melaksanakan pendidikan di Indonesia.

Pancasila memiliki serangkaian nilai, yaitu ketuhanan, kemanusiaan, persatuan, kerakyatan, dan keadilan. Kelima nilai tersebut merupakan satu kesatuan yang utuh dimana mengacu dalam tujuan yang satu. Nilai-nilai dasar Pancasila seperti ketuhanan, kemanusiaan, persatuan, kerakyatan, dan keadilan yang bersifat universal, objektif, artinya nilai-nilai tersebut dapat dipakai dan diakui oleh negara-negara lain. Sebagai suatu ideologi bangsa dan Negara Indonesia maka Pancasila pada hakikatnya bukan hanya merupakan suatu hasil perenungan atau pemikiran seseorang atau kelompok orang sebagaimana idelogiideologi lain di dunia, namun Pancasila diangkat dari nilai-nilai adat-istiadat, nilai-nilai kebudayaan serta nilai religius yang terdapat dalam pandangan hidup masyarakat Indonesia.

Globalisasi membawa perubahan-perubahan dalam tatanan dunia internasional yang pengaruhnya langsung terhadap perubahan-perubahan di berbagai Negara. Kemampuan menghadapi tantangan yang amat dasar dan akan melanda kehidupan nasional, sosial, dan politik, bahkan mental dan bangsa maka benteng yang terakhir ialah keyakinan nasional atas dasar Negara Pancasila yang sebagai benteng dalam menghadapi tantangan pada era Globalisasi yang semakin berkembang pada saat ini. Menerapkan nilai-nilai Pancasila bagi peserta didik di era globalisasi bisa dilaksanakan dalam momentum-momentum yang tepat seperti pada saat peringatan hari sumpah pemuda, hari kemerdekaan, hari pahlawan dan hari besar nasional lainnya, peserta didik berusaha mengukir prestasi yang gemilang, belajar dengan sungguh-sungguh dengan segenap kemampuannya demi nama baik bangsa dan Negara, cinta serta bangga tanpa malu-malu menggunakan produk-produk dalam negeri demi kemajuan ekonomi Negara.
\end{abstract}

Kata kunci: Pancasila, Peserta didik, Globalisasi

\footnotetext{
*Dosen Fakultas Keguruan dan Ilmu Pendidikan Universitas Muhammadiyah Ponorogo
} 
PENDAHULUAN

\section{Latar Belakang}

Peserta didik adalah anggota masyarakat yang berusaha mengembangkan potensi diri melalui proses pembelajaran yang tersedia pada jalur, jenjang, dan jenis pendidikan tertentu. Untuk itu Undang-Undang Nomor 20 Tahun 2003 tentang Sistem Pendidikan Nasional dalam pasal 3 menyebutkan bahwa Pendidikan nasional berfungsi mengembangkan kemampuan dan membentuk watak serta peradaban bangsa yang bermartabat dalam rangka mencerdaskan kehidupan bangsa, bertujuan untuk berkembangnya potensi peserta didik agar menjadi manusia yang beriman dan bertakwa kepada Tuhan Yang Maha Esa, berakhlak mulia, sehat, berilmu, cakap, kreatif, mandiri, dan menjadi warga negara yang demokratis serta bertanggung jawab.

\section{Dalam} rangka mengembangkan potensi peserta didik agar menjadi manusia yang beriman dan bertakwa kepada Tuhan Yang Maha Esa, berakhlak mulia, sehat, berilmu, cakap, kreatif, mandiri, dan menjadi warga negara yang demokratis serta bertanggung jawab, maka diperlukannya pendidikan yang tidak terlepas dari ajaran Pancasila sebagai dasar untuk melaksanakan pendidikan di Indonesia.

$$
\text { Perlu diketahui bahwa }
$$
sekarang ini banyak peserta didik dan generasi muda yang moralnya rusak karena berbagai hal yang mempengaruhi mereka diantaranya karena dampak buruk globalisasi, teman bergaul, media elektronik yang semain canggih, narkoba, minuman keras, dan hal-hal negatif lainnya. Keadaan yang demikian sangat memprihatinkan dan perlu perhatian khusus karena mereka adalah generasi penerus bangsa yang akan meneruskan perjuangan-perjuangan generasi tua membangun bangsa Indonesia. Namun jika sebelum tiba waktu mereka untuk turut serta dalam pembangunan bangsa ini, akhlak dan moral mereka sudah rusak. Tentu tidak akan maju Negara ini jika dibangun oleh generasi yang tiak bermoral. Untuk itu perlu pembenahan-pembenahan agar generasi penerus yang mendatang memiliki akhlak dan moral yang baik.

Kelangsungan hidup negara Indonesia di era globlalisasi, 
mengharuskan kita untuk mengupayakan penerapan nilai-nilai Pancasila, agar generasi penerus bangsa yang akan datang tetap dapat menghayati dan mengamalkannya dan nilai-nilai yang luhur itu tetap menjadi pedoman bangsa Indonesia sepanjang masa.

\section{Rumusan Masalah}

Rumusan masalah dari penulisan makalah ini:

1. Apa saja nilai-nilai yang terkandung dalam Pancasila?

2. Bagaimana makna Pancasila sebagai Ideologi?

3. Apa saja tantangan Pancasila sebagai ideologi Negara di era globalisasi?

4. Bagaimana implementasi nilainilai Pancasila bagi peserta didik di era globalisasi?

\section{Tujuan}

Tujuan dari penulisan makalah ini untuk memahami:

1. Nilai-nilai yang terkandung dalam Pancasila

2. Makna Pancasila sebagai ideologi

3. Tantangan Pancasila sebagai ideologi Negara di era globalisasi
4. Menerapkan nilai-nilai Pancasila bagi peserta didik di era globalisasi

\section{PEMBAHASAN}

\section{Nilai-Nilai yang Terkandung dalam Pancasila}

Sebagai suatu dasar filsafat Negara maka sila-sila Pancasila merupakan suatu sistem nilai, oleh karena itu sila-sila Pancasila itu pada hakikatnya merupakan suatu kesatuan (Kaelan dan Zubaidi, 2007: 31). Pancasila memiliki serangkaian nilai, yaitu ketuhanan, kemanusiaan, persatuan, kerakyatan, dan keadilan.

Nilai-nilai dasar Pancasila seperti ketuhanan, kemanusiaan, persatuan, kerakyatan, dan keadilan yang bersifat universal, objektif, artinya nilai-nilai tersebut dapat dipakai dan diakui oleh negara-negara lain. Pancasila bersifat subjektif, artinya bahwa nilai-nilai Pancasila itu melekat pada pembawa dan pendukung nilai Pancasila itu sendiri, yaitu masyarakat, bangsa, dan negara Indonesia.

Nilai-nilai Pancasila juga merupakan suatu pandangan hidup bangsa Indonesia. Pancasila juga merupakan nilai-nilai yang sesuai dengan hati nurani bangsa 
Indonesia, karena bersumber pada kepribadian bangsa. Nilai-nilai Pancasila ini menjadi landasan dasar, serta motivasi atas segala perbuatan baik dalam kehidupan sehari-hari dan dalam kenegaraan. Dalam kehidupan kenegaraan, perwujudan nilai Pancasila harus tampak dalam suatu peraturan perundangan yang berlaku di Indonesia. Karena dengan tampaknya Pancasila dalam suatu peraturan dapat menuntun seluruh masyarakat dalam atau luar kampus untuk bersikap sesuai dengan peraturan perundangan yang disesuaikan dengan Pancasila.

Adapun nilai-nilai yang terkandung dalam setiap sila Pancasila adalah sebagai berikut:

1. Ketuhanan Yang Maha Esa

Dalam sila Ketuhanan yang Maha Esa terkandung nilai bahwa Negara yang didirikan adalah sebagai pengejawantahan tujuan manusia sebagai makhluk Tuhan yang Maha Esa. Oleh karena itu segala hal yang berkaitan dengan pelaksanaan dan penyelengaraan Negara bahkan moral Negara, moral penyelengara Negara, politik Negara, pemerintahan Negara, hukum dan peraturan perundngundangan Negara, kebebasan dan hak asasi warga Negara harus dijiwai nilai-nilai Ketuhanan Yang Maha Esa (Kaelan dan Zubaidi, 2007: 31-32).

2. Kemanusiaan yang Adil dan Beradab

Dalam sila kemanusiaan terkandung nilai-nilai bahwa negara harus menjunjung tinggi harkat dan martabat manusia sebagai makhluk yang beradab (Kaelan dan Zubaidi, 2007: 32). Sila kedua Pancasila mengandung nilai suatu kesadaran sikap moral dan tingkah laku manusia yang didasarkan pada norma-norma dan kebudayaan baik terhadap diri sendiri, sesama manusia, maupun terhadap lingkungannya.

3. Persatuan Indonesia

Sifat kodrat manusia monodualis yaitu sebagai makhluk individu dan sebagai makhluk sosial. Untuk itu manusia memiliki perbedaan individu, suku, ras, kelompok, golongan, maupun agama. Konsekuensinya di dalam Negara adalah beraneka ragam tetapi mengkatkan diri dalam suatu kesatuan dalam semboyan "Bhineka Tunggal Ika".

4. Kerakyatan yang Dipimpin oleh Hikmat Kebijaksanan dalam Permusyawaratan/Perwakilan 
Rakyat merupakan subjek pendukung pokok Negara (Kaelan dan Zubaidi, 2007: 35). Negara merupakan dari rakyat, oleh rakyat, dan untuk rakyat sehingga rakyat merupakan asal mula kekuasaan Negara. Dalam sila keempat terkandung nilai demokrasi yang harus dilaksanakan dalam kehidupan negara.

5. Keadilan Sosial bagi Seluruh Rakyat Indonesia

Konsekuensi nilai keadilan yang harus terwujud adalah: 1) keadilan distributif (hubungan keadilan antara Negara terhadap warga negaranya), (2) keadilan legal (keadilan antara warga Negara terhadap negara), dan (3) keadilan komutatif (hubungan keadilan antara warga negara satu dengan lainnya).

Pancasila sebagai dasar Negara, pandanga hidup bangsa Indonesia, dan sebagai ideologi bangsa, menurut Suko Wiyono (2013, 95-96) memuat nilai-nilai/karakter bangsa Indonesia yang tercermin dalam sila-sila Pancasila sebagai berikut:

1. Nilai-nilai Ketuhanan Yang Maha Esa: terkandung di dalamnya prinsip asasi (1) Kepercayaan dan
Ketaqwaan kepada Tuhn Yang Maha Esa; (2) kebebasan beragama dan berkepercayaan paa Tuhan Yang Maha Esa sebagai hak yang paling asasi bagi manusia; (3) toleransi di antara umat beragama dan berkepercayaan kepada Tuhan Yang Maha Esa; dan (4) Kecintaan pada semua makhluk ciptaan Tuhan, khususnya makhluk manusia.

2. Nilai-nilai Kemanusiaan yang Adil dan Beradab: terkandun di dalamnya prinsip asasi

Kecintaan kepada sesama manusia sesuai dengan prinsip bahwa kemanusiaan adalah satu adanya; (2) Kejujuran;

Kesamaderajatan manusia;

Keadilan; dan (5) Keadaban.

3. Nilai-nilai Persatua Indonesia: terkandung di dalamnya prinsip asasi (1) Persatuan;

Kebersamaan; (3) Kecintaan pada bangsa; (4) Kecintaan pada tanah air; dan (5) Bhineka Tunggal Ika.

4. Nilai-nilai Kerakyatan yang Dipimpin oleh Hikmat Kebijaksanaan dalam Permusyawaratan/Perwakilan: terkandung di dalamnya prinsip 
asasi (1) Kerakyatan; (2) bersifat tetap yang harus dicapai, Musyawarah mufakat;

Demokrasi; $\quad$ (4) Hikmat

kebijaksanaan, dan (Perwakilan).

5. Nilai-nilai Keadilan Sosial bagi

Seluruh Rakyat Indonesia: terkandung di dalamnya prinsip asasi (1) Keadilan; (2) Keadilan sosial; (3) Kesejahteraan lahir dan batin; (4) Kekeluargaan dan kegotongroyongan; (5) Etos kerja.

\section{Makna Pancasila sebagai Ideologi}

Ideologi memainkan peranan yang penting dalam proses dan memeliara integrasi nasional, terutama di negara-negara yang sedang berkembang seperti Indonesia (Ubaidillah, 2000). Istilah ideologi berasal dari kata 'idea' berarti gagasan, konsep, pengertian dasar, cita-cita, dan 'logos' berarti ilmu. Kata idea sendiri berasal dari bahasa Yunani 'eidos' yang artinya bentuk. Selanjutnya ada kata 'idein' yang artinya melihat. Maka secara harafiah, ideologi berarti ilmu pengertianpengertian dasar. Dalam pengertian sehari-hari, 'idea' disamakan artinya dengan 'cita-cita'. Cita-cita yang dimaksud adalah cita-cita yang sehingga cita-cita yang bersifat tetap itu sekaligus merupakan dasar, pandangan atau faham (Kaelan, 2010: 113).

Ideologi berkaitan dengan tertib sosial, dan tertib politik yang ada, berupaya untuk secara sadar sisteatis mengubah, mempertahankan tertib masyarakat. Suatu pemikiran mendalam, menyeluruh, menjadi ideologi apabila pemikiran, gagasangagasan tersebut secara praktis difungsikan ke dalam lembagalembaga politik suatu masyarakat, suatu bangsa, suatu negara (Suparlan, 2012: 242).

Ideologi Negara dan ideologi bangsa dapat dikatakan sebagai suatu pemikiran yang mendalam, diyakini kebenarannya oleh suatu bangsa dalam mempersatukan gerak langkah suatu kelompok, golongan, dan partai untuk menyatukan diri, menyerasikan diri secara berdaya guna dalam kehidupan politik, tingka laku politik, tujuan politik suatu Negara dalam upaya mewujudkan tujuan nasional Indonesia berdasarkan kepentingan nasional Negara.

Sebagai suatu ideologi bangsa dan Negara Indonesia maka Pancasila 
pada hakikatnya bukan hanya merupakan suatu hasil perenungan atau pemikiran seseorang atau kelompok orang sebagaimana idelogiideologi lain di dunia, namun Pancasila diangkat dari nilai-nilai adat-istiadat, nilai-nilai kebudayaan serta nilai religius yang terdapat dalam pandangan hidup masyarakat Indonesia sebelum membentuk Negara, dengan lain perkatan unsurunsur yang merupakan materi (bahan) Pancasila tidak lain diangkat dari pandangan hidup masyarakat Indonesia sendiri, sehingga bangsa ini merupakan kausa materialis (asal bahan) Pancasila (Kaelan dan Zubaidi, 2007: 30-31).

Pendidikan Pancasila pada dasarnya merupakan rumpun pendidikan kewarganegaraan yang mengkhususkan diri pada penanaman ideologi Pancasila ke dalam pribadi peserta didik sebagai warga negara Indonesia yang baik. Dengan kata lain, Pendidikan Pancasila adalah pendidikan ideologi di Indonesia (Margono, 2012: 1).

Pancasila sebagai ideologi nasional mengatasi faham perseorangan, golongan, sukubangsa, dan agama. Sehingga semboyan
'Bhineka Tungga Ika' diterapkan bagi segala masyarakat Indonesia dalam kesatuan yang utuh Negara Kesatuan Republik Indonesia. Pancasila sebagai ideologi nasional berupaya meletakkan kepentingan bangsa dan Negara Indonesia ditempatkan dalam kedudukan utama di atas kepentingan yang lainnya. Sehingga kepentingan pribadi, golongan, dan kelompok menjadi nomor dua setelah adanya kepentingan nasional.

Kedudukan Pancasila sebagai ideologi bangsa dan Negara Indonesia, tercantum di dalam pembukaan UUD 1945 sebagai dasar Negara Kesatuan Republik Indonesia (NKRI) yang haus dilaksanakan secara konsisten dan berkesinambungan dalam kehidupan berbangsa dan bernegara. Dasar Negara yang tercantum di dalam pembukaan UUD 1945 alenia keempat tersebut, mengandung makna bahwa ideologi nasional tersebut sebagai cita-cita dan tujuan Negara.

Dengan demikian, Pancasila sebagai ideologi bangsa adalah sebagai keseluruhan pandangan, citacita, keyakinan, dan nilai-nilai bangsa Indonesia yang harus 
diimplementasikandalam kehidupan, Pancasila adalah sumber motivasi bermasyarakat, berbangsa dan inspirasi, pedoman berperilaku bernegara. sekaligus standar pembenarannya. Dengan demikian gerak ide, pola

3. Tantangan Pancasila sebagai Ideologi Negara di Era Globalisasi

Globalisasi membawa
perubahan-perubahan dalam tatanan
dunia internasional yang pengaruhnya
langsung terhadap perubahan-
perubahan di berbagai Negara. Salah
satu dampak dari perubahan-
perubahan tersebut
kecenderungan adanya
nasionalisme bangsa Indonesia. Maka
dari itu bangsa Indonesia wajib
meningkatkan kewapadaan nasional
dan ketahanan mental dan ideologi
bangsa Indonesia. Kemampuan
menghadapi tantangan yang amat
dasar dan akan melanda kehidupan
nasional, sosial, dan politik, bahkan
mental dan bangsa maka benteng
yang terakhir ialah keyakinan
nasional atas dasar Negara Pancasila
yang sebagai benteng dalam
menghadapi tantangan pada era
Globalisasi yang semakin
berkembang pada saat ini.
kepribadian bangsa Indonesia,
aktivitas, perilaku, serta hasil perilaku bangsa Indonesia harus bercermin pada Pancasila (Untari, 2012: 22). Sehingga Pancasila hendaknya mampu menyaring dampak dari Globalisasi yang mampu membawa perubahan pada tatanan dunia khususnya bagi masyarakat Indonesia. Dengan berpegang teguh pada Pancasila maka masyarakat Indonesia mampu mewujudkan nasionalisme Indonesia.

Tantangan Pancasila di era globalisasi yang bisa mengancam eksistensi kepribadian bangsa, dan kini mau tak mau, suka tidak suka, bangsa Indonesia berada di pusaran arus globalisasi dunia. Tetapi harus diingat bahwa bangsa dan negara Indonesia tidak seharusnya kehilangan jati diri, karena hidup di antara pergaulan dunia.

\section{Implementasi Nilai-Nilai Pancasila bagi Peserta Didik di Era Globalisasi}

Globalisasi merupakan hal yang tidak bisa dihindari bagi 
masyarakat dunia khususnya pada masyarakat Indonesia. Untuk itu diperlukannya penumbuhan kembali Pancasila agar tetap menjadi kajian generasi muda khususnya para peserta didik, yaitu salah satunya dapat dimulai dari pendidikan yang ada di Indonesia, misalnya dari pendidikan Sekolah Dasar hingga Sekolah Menengah Atas atau bahkan hingga ke Perguruan Tinggi. Hal ini dikarenakan, Pancasila memiliki kaitan erat dengan pendidikan pada umumnya, dan secara khusus pada Pendidikan Pancasila dan Kewarganegaraan PPKn (Hidayatillah, 2014). Implementasi nilai-nilai Pancasila di era globalisasi bagi peserta didik bisa dilaksanakan dengan menumbuhkan sifat nasionalisme pada peserta didik. Nasionalisme dapat dipupuk kembali dalam momentum-momentum yang tepat seperti pada saat peringatan hari sumpah pemuda, hari kemerdekaan, hari pahlawan dan hari besar nasional lainnya, guru maupun dosen yang tulus mengajar dengan baik dan ikhlas menuntun para siswa hingga mampu mengukir prestasi yang gemilang, pelajar yang belajar dengan sungguh-sungguh dengan segenap kemampuannya demi nama baik bangsa dan Negara, cinta serta bangga tanpa malu-malu menggunakan produk-produk dalam negeri demi kemajuan ekonomi Negara. Bukan itu saja nasionalisme juga dapat dibangun melalui karya seni seperti menciptakan lagu-lagu yang berslogan cinta tanah air, melukis, seni peran yang bertajuk semangat juang untuk negara dan karya-karya seni lainnya.

Menumbuhkan semangat nasionalisme yang tangguh, misal semangat mencintai produk dalam negeri. Menanamkan dan mengamalkan nilai- nilai Pancasila dengan sebaik- baiknya. Menanamkan dan melaksanakan ajaran agama dengan sebaik- baiknya. Mewujudkan supremasi hukum, menerapkan dan menegakkan hukum dalam arti sebenar- benarnya dan seadil- adilnya. Selektif terhadap pengaruh globalisasi di bidang politik, ideologi, ekonomi, sosial budaya bangsa (Alim, $2011: 11$ ).

\section{KESIMPULAN}

\section{Pancasila} memiliki serangkaian nilai, yaitu ketuhanan, kemanusiaan, persatuan, kerakyatan, 
dan keadilan. Nilai-nilai dasar dengan menumbuhkan sifat Pancasila seperti ketuhanan, nasionalisme pada peserta didik. kemanusiaan, persatuan, kerakyatan, Nasionalisme dapat dipupuk kembali dan keadilan yang bersifat universal, dalam momentum-momentum yang objektif, artinya nilai-nilai tersebut tepat seperti pada saat peringatan hari dapat dipakai dan diakui oleh negara- sumpah pemuda, hari kemerdekaan, negara lain. Pancasila bersifat hari pahlawan dan hari besar nasional subjektif, artinya bahwa nilai-nilai lainnya, guru maupun dosen yang Pancasila itu melekat pada pembawa dan pendukung nilai Pancasila itu sendiri, yaitu masyarakat, bangsa, dan negara Indonesia.

Sebagai suatu ideologi bangsa dan Negara Indonesia maka Pancasila pada hakikatnya bukan hanya merupakan suatu hasil perenungan atau pemikiran seseorang atau kelompok orang sebagaimana idelogiideologi lain di dunia, namun Pancasila diangkat dari nilai-nilai adat-istiadat, nilai-nilai kebudayaan serta nilai religius yang terdapat dalam pandangan hidup masyarakat Indonesia sebelum membentuk Negara, dengan lain perkatan unsurunsur yang merupakan materi (bahan) Pancasila tidak lain diangkat dari pandangan hidup masyarakat Indonesia sendiri.

$$
\text { Implementasi nilai-nilai }
$$

Pancasila di era globalisasi bagi peserta didik bisa dilaksanakan tulus mengajar dengan baik dan ikhlas menuntun para siswa hingga mampu mengukir prestasi yang gemilang, pelajar yang belajar dengan sungguh-sungguh dengan segenap kemampuannya demi nama baik bangsa dan Negara, cinta serta bangga tanpa malu-malu menggunakan produk-produk dalam negeri demi kemajuan ekonomi Negara.

\section{DAFTAR PUSTAKA}

Al-Hakim, Suparlan, dkk. 2012. Pendidikan Kewarganegaraan dalam Konteks Indonesia. Malang: Universitas Negeri Malang

Alim, Muhammad, Aziiz Al. 2011. Implementasi Nilai-Nilai Pancasila untuk Menumbuhkan Nasionalisme Bangsa. Yogyakarta: STMIK "AMIKOM" Yogyakarta

Hidayatillah, Yetti. 2014. Urgensi Eksistensi Pancasila di Era Globasilasi (Studi Kritis Terhadap Persepsi Mahasiswa STKIP PGRI Sumenep tentang Eksistensi 
Pancasila). Jurnal volume 6 nomor 2 Juni 2014.

Kaelan. 2010. Pendidikan Pancasila. Yogyakarta: Paradigma

Kaelan, \& Zubaidi, Ahmad. 2007. Pendidikan Kewarganegaraan untuk Perguruan Tinggi. Yogyakarta: Paradigma

Margono. 2012. “Lndasan dan Tujuan Pendidikan Pancasila" dalam Margono (Ed). Pendidikan Pancasila Topik Aktual Kenegaraan dan Kebangsaan. Malang: Universitas Negeri Malang (UM Press)

Sri Untari. 2012. "Pancasila dalam Kehidupan Berasyarakat, Berbangsa, dan Bernegara" dalam Margono (Ed). Pendidikan Pancasila Topik Aktual Kenegaraan dan Kebangsaan. Malang: Universitas Negeri Malang (UM Press)

Ubaidiah, A, dkk. 2000. Pendidikan kewarganegaraan (Civic Education), Demokrasi, HAM, \& Masyarakat Madani. Jakarta: IAIN Jakarta Press

Undang-Undang Nomor 20 Tahun 2003 tentang Sistem Pendidikan Nasional

Wiyono, Suko. 2013. Reaktualisasi Pancasila dalam Kehidupan Berbangsa dan Bernegara. Malang: Universitas Wisnuwardhana Malang Press 